\title{
CORRECTION
}

\section{Correction: mPGES-1 null mice are resistant to bleomycin-induced skin fibrosis}

\author{
Matthew R McCannn', Roxana Monemdjou²†, Parisa Ghassemi-Kakroodi', Hassan Fahmi', Gemma Perez², Shangxi Liu', \\ Xu Shi-wen³, Sunil K Parapuram', Fumiaki Kojima4', Christopher P Denton³, David J Abraham³, Johanne Martel-Pelletier², \\ Leslie J Crofford ${ }^{4}$, Andrew Leask ${ }^{1+}$ and Mohit Kapoor ${ }^{2 *+}$
}

See related research by McCann et al., http://arthritis-research.com/content/13/1/R6

\section{Correction}

Following publication of our recent article [1], an error in Figure $5 \mathrm{~d}$ was noticed. In Figure $5 \mathrm{~d}$, the $\beta$-actin blot corresponding to $\alpha$-SMA blot was captured on the chemiluminescence imaging system in an inverted orientation. Since this imager does not capture the protein marker, an error in the orientation of the membrane while capturing the picture of the blot occurred. During preparation of the figures for Figure $5 \mathrm{~d}$, the $\alpha$-SMA blot was in right orientation but since orientation of $\beta$-actin blot was inverse as it was captured inversely resulted in non-corresponding $\beta$-actin blot with respect to $\alpha$-SMA blot. We have rectified this error now and $\beta$-actin blot now corresponds to $\alpha$-SMA blot. The corrected figure 5 is given here as Figure 1 and a supplementary figure 1 (Additional file 1) showing another set of blots representing Figure $5 \mathrm{~d}$ is also provided.

\footnotetext{
Author details

'The Canadian Institute of Health Research Group in Skeletal Development and Remodeling, Division of Oral Biology and Department of Physiology and Pharmacology, Schulich School of Medicine and Dentistry, University of Western Ontario, Dental Sciences Building, London, Ontario, N6A 5C1, Canada. ${ }^{2}$ Osteoarthritis Research Unit, University of Montreal Hospital Research Center (CR-CHUM) and Department of Medicine, University of Montreal, 1560 Rue Sherbrooke Est, Montréal, Québec, H2L 4M1, Canada. ${ }^{3}$ Centre for Rheumatology, Department of Medicine, University College London (Royal Free Campus), Rowland Hill Street, London, NW3 2PF, UK. ${ }^{4}$ Division of Rheumatology, Department of Internal Medicine, University of Kentucky, 740 S. Limestone Street, J-509 Kentucky Clinic, Lexington, KY 40536, USA.
}

Additional material

\begin{abstract}
Additional file 1
Supplementary Figure 1. mPGES-1 genetic deletion results in reduced a-SMA expression in response to bleomycin treatment.

Description. Protein extracts from skin tissue after 4 weeks of bleomycin or PBS treatment were subjected to Western blot analysis with an anti-a-SMA antibody. mPGES-1 null mice treated with bleomycin showed reduced a-SMA expression compared with bleomycin-treated WT mice. Representative blot from four separate animals/group/genotype is shown. (b) Graph represents a-SMA expression normalized to $\beta$-actin expression from four separate animals/group/genotype. ${ }^{*} P<0.05$; bleomycin-treated WT and mPGES-1 null mice compared with PBS-treated mice. ${ }^{+} P<0.05$; bleomycin-treated mPGES-1 null mice compared with bleomycintreated WT mice. a-SMA, alpha-smooth muscle actin; $\beta$-actin, betaactin; mPGES-1, microsomal prostaglandin $\mathrm{E}_{2}$ synthase-1.
\end{abstract}

Format. JPG. Download file at: http://arthritis-research.com/content/ supplementary/ar3285-s1.jpg

\section{Published: 24 March 2011}

\section{References}

1. McCann MR, Monemdjou R, Ghassemi-Kakroodi, P, Fahmi H, Perez G, Liu S, Shi-wen X, Parapuram SK, Kojima F, Denton CP, Abraham DJ, Martel-Pelletier J, Crofford $L$, Leask A, Kapoor M: mPGES-1 null mice are resistant to bleomycin-induced skin fibrosis. Arthritis Res Ther 2011, 13:R6.

doi:10.1186/ar3285

Cite this article as: McCann MR, et al: Correction: $\mathrm{mPGES}-1$ null mice are resistant to bleomycin-induced skin fibrosis. Arthritis Research \& Therapy 2011, 13:402.

\footnotetext{
*Correspondence: mohit.kapoor.chum@ssss.gouv.qc.ca

${ }^{+}$Contributed equally

${ }^{2}$ Osteoarthritis Research Unit, University of Montreal Hospital Research Center

(CR-CHUM) and Department of Medicine, University of Montreal, 1560 Rue

Sherbrooke Est, Montréal, Québec, H2L 4M1, Canada

Full list of author information is available at the end of the article
} 


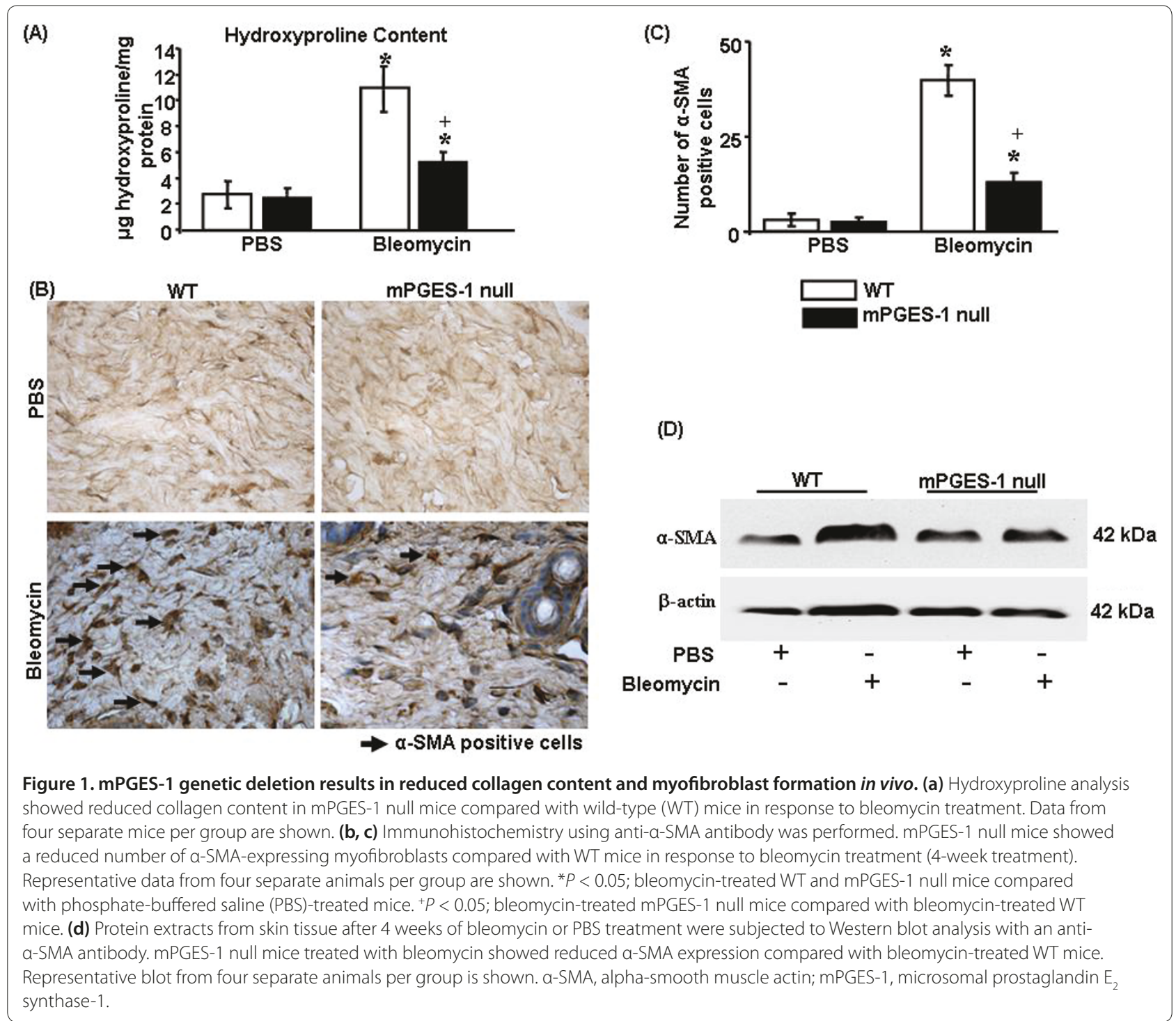

